\title{
The effect of the silting phenomenon on the characteristic volumes and the lake basins in the Someşul Cald reservoirs cascade system
}

\author{
Gh. Şerban \\ Faculty of Geography, "Babeş-Bolyai” University, Cluj-Napoca, \\ România
}

\begin{abstract}
The observations and measurements realised throughout the years on the Someşul Cald reservoirs cascade system confirm the existence of some specific risk elements (silting, reduction of characteristic volumes, changes of the aquatic environment etc.). The cooperation with the specialized units engaged in the administration of lakes (The Romanian Water Authority - "Someş-Tisa" Cluj Water Department, S. C. Hidroelectrica S.A. - Cluj Branch, S. C. "Someş" S.A. Cluj Water Company), has proved fruitful, as they have made it possible to supplement the information database. The application of digital analysis and G.I.S. technology in the data processing and modelling made the attainment of some important conclusions possible, as well as the establishment of the shortterm tendencies of evolution of the phenomena and processes in the basins. The results obtained were applied to the activity performed by the forementioned institutions.
\end{abstract}

Keywords: reservoirs, silting, characteristic volumes, silting trend.

\section{Introduction}

With a full capacity of more than 330 million $\mathrm{m}^{3}$, the four reservoirs of the Someşul Cald Valley (Fântânele, Tarnița, Someşul Cald and Gilău) represent an important water reserve capitalized energetically and supplying water for an extensive area and a large number of inhabitants (more than 600,000). Their location toward the outskirts of the northern part of the Apuseni Mountains (in the area of outcrop of the sedimentary rocks) and in the neighbourhood of a large city (Cluj-Napoca) determined the appearance of numerous elements of risks in the optimum exploitation of the potential of the basins, see fig. 1. 


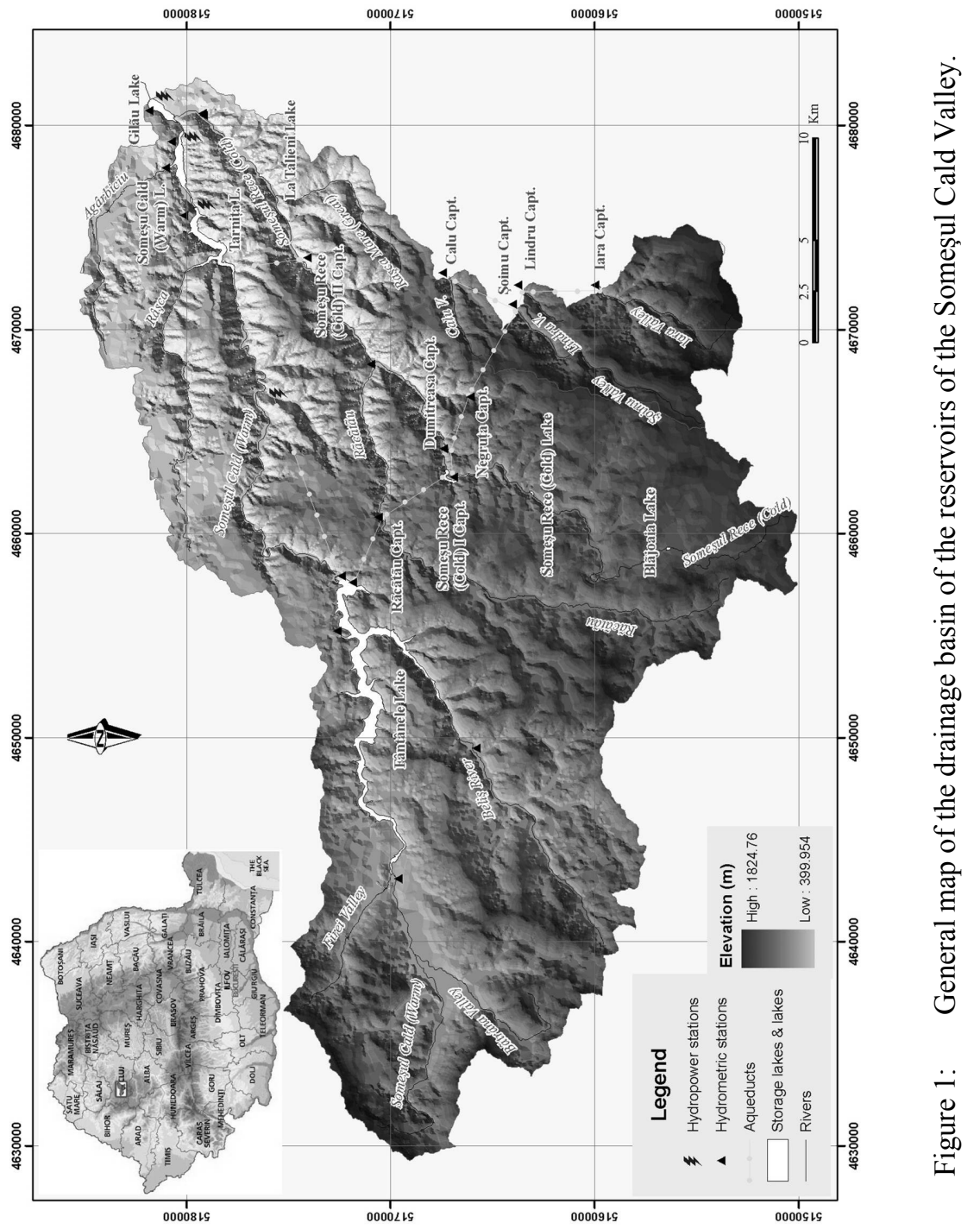

WIT Transactions on Information and Communication, Vol 39, (c) 2008 WIT Press www.witpress.com, ISSN 1743-3517 (on-line) 
If the presence of the anthropogenic flows (especially the tourist flows) has determined the qualitative degradation of these waters, the sedimentary rocks from the drainage basin have favoured a high rate of sedimentation.

\section{The reservoirs of the Someşul Cald Valley}

The most important system of cascade reservoirs in Transylvania comprises four units of different sizes whose full capacity $\left(334.16 \mathrm{mil}^{3} \mathrm{~m}^{3}\right.$ ) represents $72 \%$ of the volume of all the reservoirs of the Someş drainage basin $\left(464.32 \mathrm{mil.} \mathrm{m}^{3}\right)$. Their full water area is 1298 ha, corresponding to $1 \%$ of the total area of the Romanian hydropower reservoirs. The main values of morphometrical elements of the reservoirs are rendered in table 1.

The characteristic volumes of the reservoirs provide information about the complex functions concerning the lake units (Csermak et al [2]), see table 2.

Thus, Fântânele Lake has the following functions: the production of power, meaning the production of electrical energy in the underground hydropower station from Mărişelu, to regulate the water discharges on the Someşul Cald and on Someşul Mic rivers, to attenuate the waves of flash-flood on the same rivers.

Tarnița Lake was put in use in order to: produce electricity in the hydropower station located at the base of the dam, to regulate the water discharges on Someşul Cald and Someşul Mic rivers; to attenuate the waves of flash-flood from its drainage basin; to recover the discharges coming from the upstream hydropower station.

Table 1: $\quad$ Main morphometrical parameters of the reservoirs of the Someşul Cald drainage basin (NLR - Normal Level of Retention).

\begin{tabular}{|c|l|l|c|c|c|c|c|}
\hline $\mathrm{N}^{\mathrm{o}}$. & \multicolumn{1}{|c|}{ River } & $\begin{array}{c}\text { Storage } \\
\text { lake }\end{array}$ & $\begin{array}{c}\text { NLR (m- } \\
\text { B.S. }{ }^{*}\end{array}$ & Area (ha) & $\begin{array}{c}\text { Length } \\
\text { L }(\mathrm{km})\end{array}$ & $\begin{array}{c}\text { Maximal } \\
\text { width B(m) }\end{array}$ & $\begin{array}{c}\text { Rate } \\
\text { L/B }\end{array}$ \\
\hline 1 & $\begin{array}{l}\text { Someşul } \\
\text { Cald }\end{array}$ & Fântânele & 991 & 815 & 19.13 & 748 & 25.57 \\
\hline 2 & $\begin{array}{l}\text { Someşul } \\
\text { Cald }\end{array}$ & Tarniţa & 521.5 & 220 & 8.4 & 597.8 & 14.05 \\
\hline 3 & $\begin{array}{l}\text { Someşul } \\
\text { Cald }\end{array}$ & $\begin{array}{l}\text { Someşu } \\
\text { Cald }\end{array}$ & 441 & 85 & 4.25 & 423.5 & 10.04 \\
\hline 4 & $\begin{array}{l}\text { Someşul } \\
\text { Mic }\end{array}$ & Gilău & 420.1 & 72 & 2.34 & 497.3 & 4.7 \\
\hline
\end{tabular}

* B.S. = Black Sea

Table 2: Characteristic volumes of the reservoirs of the Someşul Cald Valley, according to the latest bathymetrical surveys.

\begin{tabular}{|c|l|c|c|c|c|c|c|}
\hline \multirow{2}{*}{ No. } & \multirow{2}{*}{$\begin{array}{c}\text { Lake/Year of } \\
\text { survey }\end{array}$} & \multicolumn{7}{|c|}{ Characteristic volumes $\left(\mathrm{mil} \mathrm{m}^{3}\right.$ ) } \\
\cline { 3 - 8 } & & Global & Raw & Attenuation & Available & Spare & Dead \\
\hline 1 & Fântânele/2000 & 244.69 & 207.59 & 37 & 186.93 & 10.17 & 10.5 \\
\hline 2 & Tarnița/2001 & 75.25 & 68.08 & 6.9 & 13.79 & 39.08 & 5.62 \\
\hline 3 & Someşu Cald/1993 & 8.45 & 6.45 & 1.99 & 0.86 & 3.41 & 2.18 \\
\hline 4 & Gilău/2005 & 3.56 & 2.45 & 1.12 & 0.61 & 1.4 & 0.44 \\
\hline
\end{tabular}


Someşul Cald Lake represents a buffer lake between Tarnița and Gilău lakes and its functions are related to: the production of electrical energy in the hydropower station located at the base of the dam; the recovery of the discharges coming from the upstream hydropower station (Tarnița); the decantation of alluvia for its tributary (Agârbiciu river) - as a matter of fact, this was one of the most important reasons in its design, to attenuate the high silting rate of Gilău reservoir, placed immediately downstream; the function of attenuation of flashfloods is insignificant due to its small characteristic volume.

Gilău Lake, is the first built and the smallest one. It has also a complex function, related to: the supply of water for an important network of settlements and economic units placed downstream - Cluj-Napoca City (population and industry), the mining regions of Căpuş and Aghireşu, the commune of Apahida and other settlements of Someşul Mic flood plain, the "AgroFlip" S.A. Bonțida unit, the towns of Gherla and, in the future, Dej; the compensation of the discharges coming from the upstream hydropower stations; the production of electricity in the hydropower station located at the base of the dam; the function of attenuation of flash-floods is insignificant due to its small characteristic volume.

\section{Risks induced by the silting of the lakes of the Someşul Cald Valley}

In the cascade systems, the evolution of the silting phenomenon is different from one lake to another, depending on their position within the system, the lithology of their catchment area, the basin morphology and, least but not last, the tributary and exiting liquid and alluvia discharges (Giurma [3]).

\subsection{Silting rate of the characteristic volumes}

For the biggest lake of the system (Fântânele) the percent values of the characteristic volume decrease during the entire existence of the lake exceed $5 \%$, except for the available volume which is placed immediately under this value. Some higher values are noticed in the case of dead volumes $(17.1 \%)$, of attenuation volume $(9.76 \%)$ and spare volume $(9.39 \%)$, because of the alluvial deposits from the tail of the lake and the mouths of the tributaries (the two last volumes), table 3.

The annual average rate of silting is reduced (below $0.40 \%$ ), with the exception of the above cases. Although, the values of the volume reduction are procentually low, they really represent an important capacity lost, equivalent for example, to the double of the global volume of the Someşul Cald lake and to four times that of the Gilău lake. The reduced silting rate is due to the resistance to erosion of the rocks of the drainage basin of the lake (granite and crystalline schists in majority) and to the thin soil developed on this bedrock.

The characteristic volumes of the Tarniţa lake have low decreasing values (below $8 \%$ ), with the exception of the spare volume $(27.8 \%)$ and the dead volume $(12.71 \%)$. The same situation shows up in the case of the annual average silting rate; its values do not exceed $0.5 \%$ except for the case of the spare volume. 
The relatively low rate of silting of this reservoir is due to its position inside the lake cascade system, to its position downstream from Fântânele lake, at shelter from the massive alluvia brought by the tributaries (excepting Someşul Rece II supply and Râşca Valley). Its drainage basin is placed on the same hard bedrock made up by crystalline schists and volcanic rocks, which are covered by a thin soil cover - except for the Râşca Valley basin.

There are three possible causes of spare volume reduction: the share of sediments brought in by Someşul Rece II supply from the drainage basin of Someşul Rece river, the sedimentations produced in the area of confluece of Someşul Cald river with its tributary Râşca Valley and the reshuffle of the sediments produced on the shores of the lake.

Someşul Cald reservoir is a lake unit with a high degree and rate of silting for some of its characteristic volumes, table 3.

There is a different evolution on two groups of characteristic volumes: the global, raw, attenuation and dead volumes are affected by high silting, while the others volumes, less. Within the first group, the dead volume stands out with the highest degree of silting (32.3\%) and a high annual average rate $(3.23 \%)$, followed by the attenuation, raw and global volumes with a rate comprised between 15.2 and $8.20 \%$, but with a low annual average rate of silting $(1.52-0.82 \%)$.

The spare volume is nearly unaffected $(0.35 \%)$, with an average rate of $0,04 \%$, while the available volume is slightly reduced with a rate of 4.22 and $0.42 \%$.

Agârbiciu river, the direct tributary of the lake, is responsible for the amplitude of the phenomenon which affects the characteristic volumes from first group. It has all its drainage basin developed on soft sedimentary rocks (stripped clay of the Lower Miocene), and one should add the massive deforestation of the basin. The situation is materialized by the important alluvial transport of this river. The measurements on the discharges of suspended alluvia performed at Someşul Cald hydrometric station, on Agârbiciu river, between 1979 and 1982, before the lake was created, pointed out an average transport of 32627.145 tonnes a year, which extrapolated to a period of 10 years, validates the degree of silting of the lake.

Gilău reservoir represents the most clogged up lake unit among the four lakes of the system. Following the data from the table 3, we can distinguish two stages in the evolution of the phenomenon, each having distinct features.

The first stage corresponds to the period 1972-1983, before the creation of Someşul Cald Lake. This stage is characterized by high percents of the decrease of all the characteristic volumes, the values ranging between 8.48 and $13.08 \%$ for the global volume, 8.34 and $16.89 \%$ for the raw volume, 2.17 and $11.06 \%$ for the attenuation volume, $4-5 \%$ for the available volume, 6.44 and $17.83 \%$ for the spare volume and $18.24-26.42 \%$ for the dead volume. The same situation is met for the annual average rate of silting.

This less favourable dynamics for the reservoir is due to the supply of alluvia from both Someşul Cald, in overwhelming proportion from the Agârbiciu basin, and from Someşul Rece. It is obvious the fact that during this period the main role in the silting phenomenon was played by the first river, aspect which is also proved by the silting evolution of Gilau Lake after the construction of the Someşul Cald lake dam. 


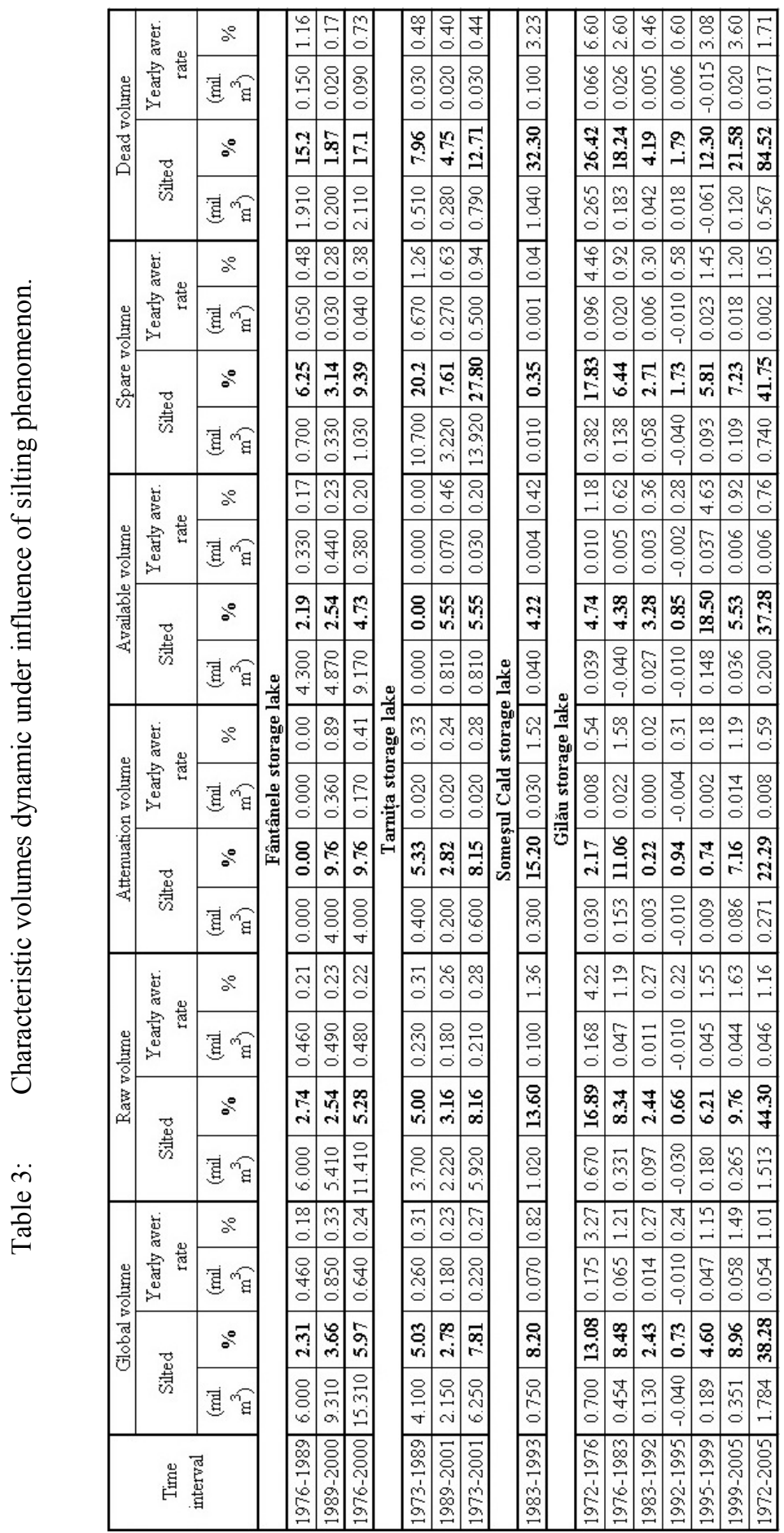


A part of this period was studied in detail by Anitan et al [1], including the granulometric analysis of the sediments laid down.

The second stage is identified with the period 1983-2005, when the evolution of the silting phenomenon was very slow in the beginning of the period, but complicated towards its end. The percents of the volumes reduction no longer exceeded the value of $4 \%$ except for the case of the dead volume (4.19). The annual average rate of silting was also kept within limits compared to the previous stage, without exceeding $1.5 \%$. In the last part of the period, the intensification and growing frequency of climatic and hydric extreme phenomena led to an overturn of the situation. After several great flash-floods, of which a catastrophic one on Someşul Rece, in December 1995, the percents of reduction of the characteristic volumes grew very much, and so did the annual average rate of silting. They varied between 4.60 and 21.58 for volumes, and between 1.15 and 3.60 , for the annual average rate of silting, with the single exception of the attenuation volume between 1995 and 1999.

Generally, the silting degree of Gilău reservoir is very advanced: $22.29 \%$ for the attenuation volume, $37.28 \%$ for the available volume, between 38 and $45 \%$ for the global, spare and raw volumes and $84.52 \%$ for the dead volume.

\subsection{Changes in lake basins morphology}

The use of GPS and echo sounder for the bathymetric measurements and the GIS techniques for the processing of the information provided, made possible the creation of 3D models, allowing the determination of the changes on the space of the lake basin, Kondratyev and Filatov [4] and Serban et al [6].

Special elements concerning the sediments distribution were not noticed in the case of the large reservoirs, Fântânele and Tarnița, the areas of high silting intensity being represented by the outlet of the main tributaries in the lakes, where alluvial cones and massive alluvial banks are formed. For the downstream reservoirs, including also Someşul Cald Lake, the repartition of the sediments on the basin bed is different, because of the low depths, the smaller capacities, the consistent alluvial share and the different water flow - buffer lakes, fig. 2 .

The consistent alluvial share (maximum in the hydrographic basin, as seen above regarding the silting rate assessment), has been scattered in another way than the natural one, due to the water flows coming from the upstream Tarnița hydro-power station. The most silted space of the basin is not at the confluence with Agârbiciu river, in the shape of an underwater alluvial cone, but on the opposite convex slope of the lake basin. The clayish sediments were reshuffled in the shape of alluvial banks, alluvial bars and longitudinal channels, deviations of thalwegs and alluvial terraces. A part of them was present also in the upper sector of the lake basin, in the calm periods between evacuations in the same configuration (Serban and Alexe [7]).

The most advanced evolution of the silting phenomenon was noticed in Gilău reservoir, where the geological factor has mostly influenced the distribution of the sediments in the basin space. The stratum of Upper Cretaceous Sandstones which crosses the lake in the median zone operates as a threshold and causes a 


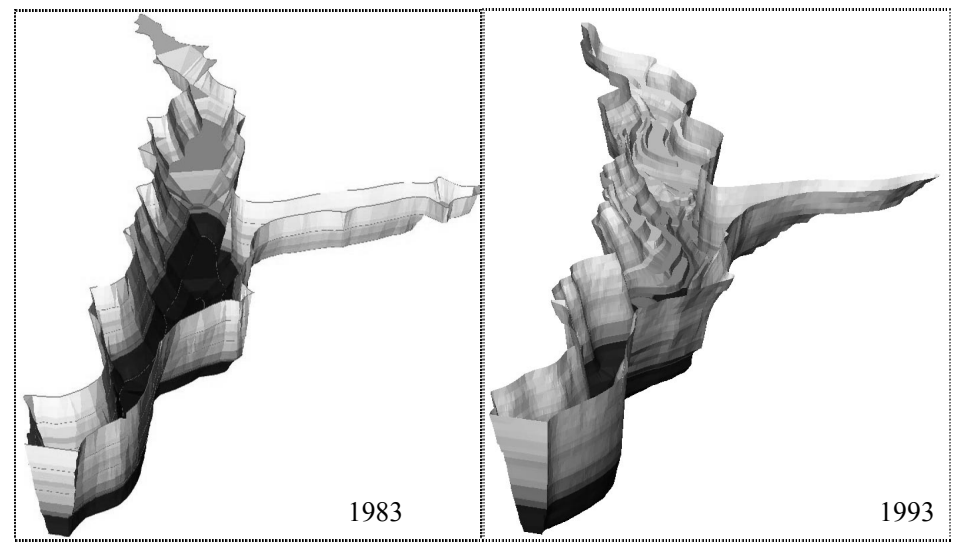

Figure 2: 3D scene of the Someşul Cald reservoir basin.

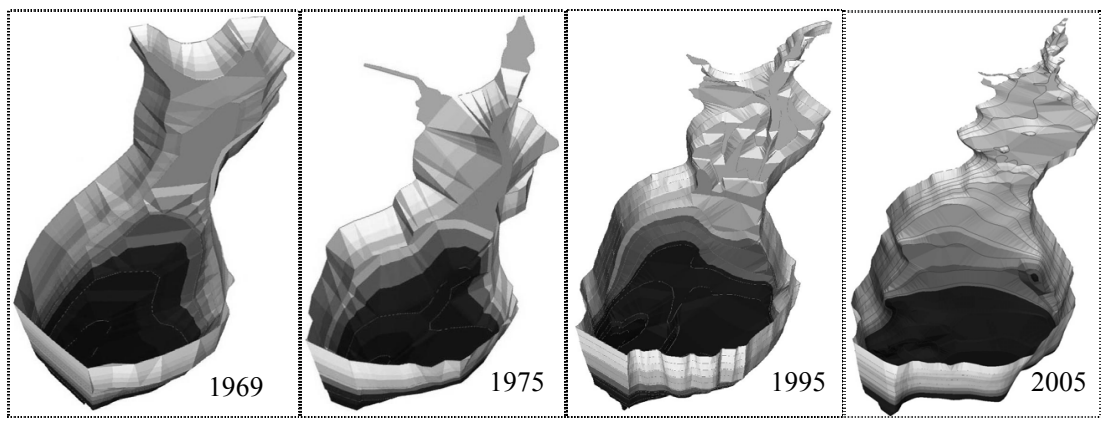

Figure 3: $\quad 3 \mathrm{D}$ scene and stages of evolution of the Gilău reservoir basin.

narrowing and the basin partition into two sectors, each of these sectors having an independent alluvial evolution, see fig. 3 .

The discrepancy concerning the silting of the two sectors appears as far back as the first years after the creation of the lake. In the upper sector of the basin, a narrowing of the former flood plain of Someşul Mic river took place in the first stage, due to the effect of the two-sided alluvial transport (Someşul Cald and Someşul Rece). Subsequently it disappears as a morphological unit (in the year 1977) to be substituted by a combination of the two rivers alluvial cones. After the year 1983, the alluvial share from the Someşul Cald becomes neglectable and the evolution of the cone ceases, while the one of Someşul Rece evolves as a small delta and the thalweg is pushed towards the left slope.

\subsection{The consequences and trend of silting}

The risks induced by the silting of reservoirs have become manifest by: the increased frequency of floods in the upstream and downstream sectors; the reduction of characteristic volumes, especially the available volume, with important implications concerning the uses (supply of water, production of energy, the flash-flood attenuation etc); the jam of the dam evacuators; the 
development of underwater vegetation playing a part in the acceleration of the silting phenomenon and in the negative effects on the quality of water; the acceleration of river-bed degradation in the sector dowstream from the dams etc.

From the point of view of the economic effect, the silting of the lakes, in different stages, can be compared with the events at the dams, Rosu and Cretu $[5]$.

Thus, the reduction of the reservoir available volume with less than $50 \%$ throughout the entire designed life of the building can be considered an incident. The reduction with $50-75 \%$ of the available volume during a period shorter than the designed life of the building, which leads to the temporary obturation of the capture front can be assimilated with an accident - type event. The reservoirs which have functions like the supply with water of communities, irrigations, leisure, fish farming, and the available volume has been reduced with about 75$90 \%$ during a shorter period than the designed life of the building, are considered to be affected to a level equivalent to the destruction of the dams.

According to the silting tendency rate and graphics, among the reservoirs of Someşul Cald river, only Gilău lake can be framed in one of the three above categories, because the silting phenomenon affects a little the available volume slice, see fig. 4.

The reduction of the lake specific capacity with $37.28 \%$ can be considered, by comparison, an incident, because it affects in a sensitive way the hydropower and water supply functions. Considering that the tributary flow in the lake becomes $0 \mathrm{~m}^{3} / \mathrm{s}$, the lake available volume would be enough for a little more
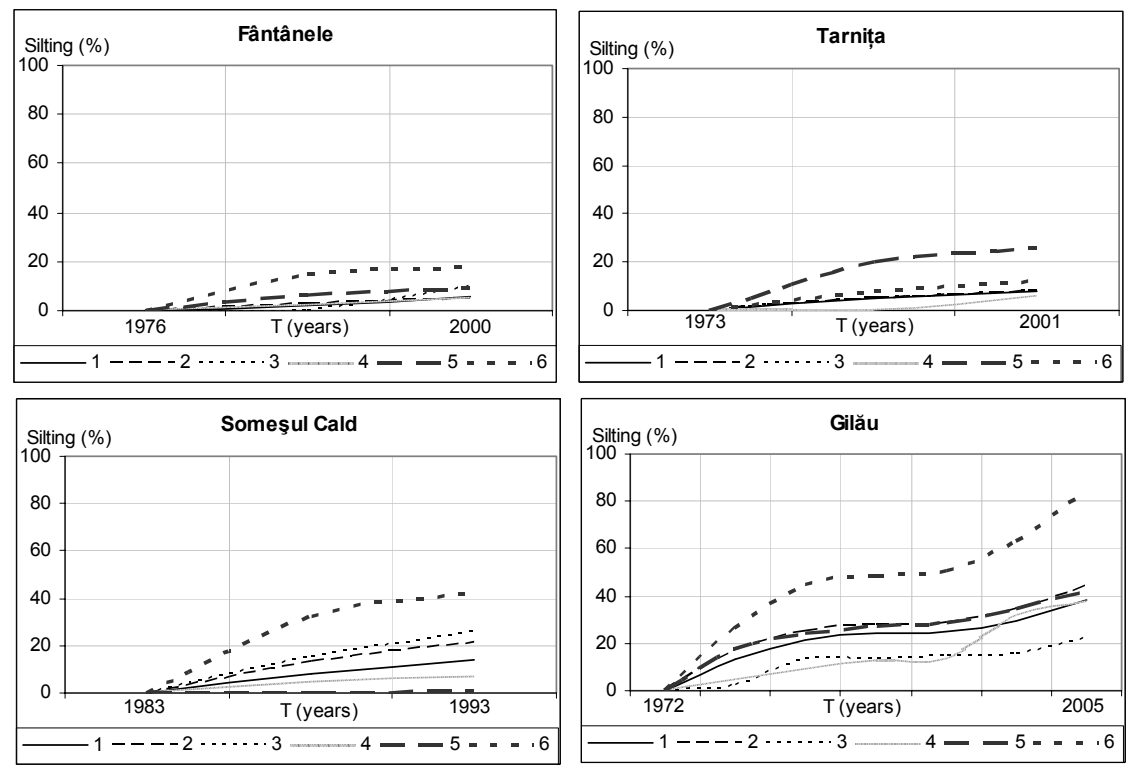

Figure 4: Characterisc volume trends for the Someşul Cald Valley reservoirs. 1, global volume; 2, raw volume; 3, attenuation volume; 4 , available volume; 5 , spare volume; 6 , dead volume. 
than three hours for the functioning of the hydropower station and for about 49 hours for the functioning of Gilău water treatment station, which provides water for 600,000 inhabitants from the neighbouring zone.

\section{Conclusions}

The charts of the silting trend point out encouraging views of capitalization of the potential of the lakes. Less optimistic is the forecast for Someşul Cald reservoir and not at all favourable is the one for Gilău lake. Especially in last case, the silting of the dead volume part can lead to the jam of the bottomdischarge and, also, to other drawbacks in the functioning of the installations. Also, the higher frequency of climatic and hydrological risk phenomena of the last decade raises serious issues for the two downstream reservoirs, as their basin configuration and the trends of their volumes react fast to the pulsations generated by flash-floods.

In the present conditions of sedimentation, the "life" of available volume can be estimated to around 500 years for Fântânele and Tarnița reservoirs, 200 years for Someşul Cald reservoir and much less (below 90 years) for Gilău reservoir.

The silting rate may be amplified by the presence of some natural unbalances or by negative intervention of the human factor. By positive interventions, man can attenuate this phenomenon. The actions should be directed as to decrease the alluvial transport toward the reservoirs, by building small dams on the tributaries. The newly created reservoirs would collect the alluvial flow and the fill of the basin would be easier than in the case of the large reservoirs. Also, they might be used for other purposes (tourism, fishing etc).

\section{References}

[1] Anitan I., Cocut N., Farcas R., Pop Gh., Tövissi I., Ujvári I., Unele cercetari legate de colmatarea lacului de acumulare de la Gilau (Some researches on the Gilău reservoir silting), C.N.A., I.C.P.G.A., Studii de alimentari cu apa, Bucuresti, pp. 106-115, 1977.

[2] Csermák B., Krempels T., Szestay K., Nagy I.V., Ubell K., Hydrology of water storage. International post graduate course on hydrological methods for developing, Water Resources Management, No 12, Budapest, 180 p., 1970.

[3] Giurma, I., Colmatarea lacurilor de acumulare (Reservoir silting), Edit. H. G. A., Bucuresti, 170 p., 1997.

[4] Kondratyev, K.Y., Filatov, N.N., Limnology and Remote Sensing. A Contemporary Approach, Praxis Publishing Ltd, Chichester, UK, 398 p, 1999.

[5] Rosu, C., Cretu, Gh., Inundatii accidentale (Accidental floods), Edit. H.G.A., Bucuresti, 192 p, 1998.

[6] Serban, Gh., Alexe, M., Touchart, L., L'evolution du modele lacustre et la salinite des lacs de Cojocna (Plaine de Transylvanie, Roumanie) (The basin model evolution and the salinity of the lakes from Cojocna - Transylvanian Plain, Romania), Bulletin de l'Association de Geographes Francais, No 2, 
Juin, 82e annee, Section II: Lacs, etangs et zones humides: une demarche de geographie limnologique, Paris, pp. 234-245, 2005.

[7] Serban, Gh., Alexe, M., Aplicatii GIS in gospodarirea lacurilor de acumulare - studiu de caz lacul Somesul Cald (GIS applications in reservoirs management - case study: Someşul Cald Lake), Geographia Technica, Nr. 1, Edit. Cluj University Press, Cluj-Napoca, Romania, pp. 181-187, 2006. 